\title{
The Effects of Temperature Stress on the Quality and Yield of Soya Bean [(Glycine max L.) Merrill.]
}

\author{
Thuzar, M \\ Department of Agricultural Botany, Yezin Agricultural University \\ 05282 Yezin, Nay Pyi Taw, Myanmar \\ Tel: 60-173-370-458Ｅ-mail: myintthuzarupm@gmail.com
}

A. B. Puteh (Corresponding author)

Senior Lecturer, Department of Crop Science, Faculty of Agriculture

Universiti Putra Malaysia, 43400 UPM Serdang, Serdang Selangor, Malaysia

Tel: 60-3-8946-6996 E-mail: adam@agri.upm.edu.my

N. A. P. Abdullah

Senior Lecturer, Department of Crop Science, Faculty of Agriculture

Universiti Putra Malaysia, 43400,UPM Serdang, Serdang Selangor, Malaysia

Tel: 60-3-8946-7255Ｅ-mail: nurashikin@putra.upm.edu.my

M. B. Mohd. Lassim

Associate Professor, Department of Crop Science, Faculty of Agriculture

Universiti Putra Malaysia, 43400 UPM Serdang, Serdang Selangor, Malaysia

Tel: 603-8946-6923Ｅ-mail: mlasim@pc.jaring.my

Kamaruzaman Jusoff

TropAIR, Faculty of Forestry, Universiti Putra Malaysia

43400 Serdang, Selangor, Malaysia

Tel: 60-3-8946-7176 E-mail: kjusoff@yahoo.com

\begin{abstract}
Reproductive development and growth by crops is especially important for human welfare because we depend on crop fruits and seeds, directly and indirectly, for most of our food. Seed production by crops depends on vegetative development and growth, development of pollen and egg, pollination, and fertilization. The final size of individual seeds generally hinges on cell division within the embryo, followed by seed filling and maturation process. Environmental conditions prior to the shift to reproductive development usually affect by influencing photosynthesis per unit of leaf area, canopy development and interception of solar radiation per unit of ground area, and initiation of potential fruiting site; a strong positive correlation between canopy photosynthesis per unit of ground area and seed number exists for most crops. For many crops where they are now grown, an increase of just a few ${ }^{\circ} \mathrm{C}$ significantly reduce yield. Dependence on soybeans for food and feed has increased rapidly in many countries during the last 30 years. Nutritionists believe that utilization of soybeans should continue to increase in order to provide better nourishment for people throughout the world. For this goal to be realize, present production areas must produce more soybeans and new production areas must be established.
\end{abstract}

Keywords: Global warming, Pollen, Seed, Quality, Yield, Temperature, Stress, Soybean 


\section{Introduction}

The world today is face with great challenges to produce adequate food, fiber, feed, industrial products, and ecosystem services for the Earth's 6.4 billion people. With nearly 80 million added every year, we must develop ecosystem goods and services to meet the needs of 8 billion by the year 2025 and over 10 billion by 2050 (Reddy, 2005). Climatic changes associated with increasing atmospheric concentration of carbon dioxide $\left(\mathrm{CO}_{2}\right)$ and other "greenhouse gases" most importantly global warming and increasing ozone $\left(\mathrm{O}_{3}\right)$ concentrations in the lower atmosphere across large crop-growing regions. Many natural and human systems are sensitive and vulnerable to climate change. These changes occurred on local to global spatial scales. Some changes persisted or will persist for only short periods, but others will remain for centuries to come. The magnitude of present population increase is evidence that environmental changes will continue and some change may accelerate in the future because the rates of most processes driving the changes increase with population size. Many environmental changes are innocuous with respect to crop yield, production, and quality, but others are either beneficial or harmful to crops. Observational evidence indicates that recent regional changes in climate, particularly temperature increases, have already affected a diverse set of physical and biological system in many parts of the world (Beggs, 2004). Furthermore, with intensive agriculture, soil degradation and particularly Stalinization are becoming major concerns. Added to these stress comes a threat-global environmental change resulting from increased green house gas concentrations in the atmosphere because of anthropogenic activities.

Global warming will bring about heat stresses on plants that will even affect the type of crops grown. The challenges that global warming poses to agriculture requires that Agricultural Scientists develop response mechanisms to mitigate the changes ion the environment. Hence Plant breeding programmers need to make necessary changes to adopt environment-specific approaches to crop improvement (Reynolds et al., 2001).

The problem of climate change and its possible consequences on agricultural production has received much discussion of late. This problem is real. The obvious result of rising global temperatures will be heat stresses on plants that could alter agriculture with respect to types of crops grown. Agricultural Scientists have to make necessary changes to adopt environment-specific approaches to crop Improvement. Human activities such as deforestation and burning of fossil fuel are mainly responsible for the recent rapid increases in atmospheric concentrations of greenhouse gases including $\mathrm{CO}_{2}$ (Kaufmann \& Stern, 1997; Houghton et al., 2001; Stott et al., 2001). At the present rate of emission, $\mathrm{CO}_{2}$ concentration is subject to be in the range of $540-970 \mu \mathrm{mol} \mathrm{mol} \mathrm{by} \mathrm{the} \mathrm{end} \mathrm{of} \mathrm{this} \mathrm{century,} \mathrm{which} \mathrm{will} \mathrm{potentially} \mathrm{increase} \mathrm{global} \mathrm{near}$ surface temperature by $1.4-5.8^{\circ} \mathrm{C}$ (Houghton et al.,2001) with some degree of delay, global warming will occur concurrently with increase in $\mathrm{CO}_{2}$. Therefore, it is important to quantify the interactive effects of increasing temperature and $\mathrm{CO}_{2}$ on crop production.

In contrast, post-flowering conditions affect yield mainly by influencing ovary or seed abortion, or by changing seed filling duration (SFD) or seed filling rate (SFR). In general, SFD is more plastic than SFR. In spite of the importance of individual seed size, yield variation is more often due to changes in seed number per unit of ground area than to individual seed mass at maturity. Warming hastens crop development and therefore shortens the SFD. Seed number can be reduced via the direct effects of high temperature on reproduction, particularly pollen formation and function. Because warming speeds reproductive development, the seeds that do develop are often small. Although SFR is sometimes stimulated by warming, this effect often does not fully compensate for shortened SFD.

\section{Global climate change and crop production}

Global climate change has emerged as an important environment challenge due to potential impact on biological systems of planet Earth (Houghton et al., 2001). Since the beginning of the industrial revolution (about 1750), the concentrations of $\mathrm{CO}_{2}$, methane and nitrous oxide have increased by $31 \%, 150 \%$ and $16 \%$, respectively. The present day $\mathrm{CO}_{2}$ concentration $\left(370 \mu \mathrm{mol} \mathrm{mol}^{-1)}\right.$ has not been exceeded during the past 420,000 years and likely not during the past 20 million years (Petil et al., 1999). Temperature is the important controlling plant growth and development. Suitability of a crop to a given location depends not only on the threshold temperatures but also on the length of the growing season. Daily or seasonal temperatures above optimum and temperature extremes, should they coincide with critical stages of plant development, will become a major factor limiting crop production.

Several new studies have shown that the climate record of $20^{\text {th }}$ century cannot be explained solely by accounting for solar variability, volcanic eruptions and El Niño cycles. It appears more likely that greenhouse gases from human activities were the dominant drivers of these global-average temperature changes during the $20^{\text {th }}$ century. Future increase in greenhouse gases are projected to raise earth's surface temperature to anywhere between 1.5 to $11^{\circ} \mathrm{C}$ by 2100 (Stainforth et al., 2005) that would severely reduce soybean crop production. Interactive effects of temperature and $\left[\mathrm{CO}_{2}\right]$ on other legume (Ahmed et al., 1993; Prasad et al., 2002, 2003) showed that that the positive interactions observed between $\left[\mathrm{CO}_{2}\right]$ and temperature on vegetative growth can not be translated to reproductive process. The physiology effects of high- temperature stress on reproductive development under typical field conditions are more pronounced the effects on vegetative development in many crop species (Hall, 1992). 
Most studies on the effect of temperature on soybean seed yield have concentrated on increases in day temperature or concomitant increases in day/night temperature. There were no beneficial interaction between $\left[\mathrm{CO}_{2}\right]$, Temperature and UV-B radiation on reproductive development processes such as pollen production, germination and tube length of soybean. Prasad et al. (2000) investigated the effect of daytime soil and air temperature of 28 and $38^{\circ} \mathrm{C}$, from start of flowering to maturity, and reported $50 \%$ reduction in pod yield at high temperatures.

\section{Green house effect on crop production}

The greenhouse effect is an increase in the average temperature of the earth. It happens because certain gases absorb infrared heat that would normally be radiated into space. Infrared light is what you feel as heat from heat lamps used in restaurants to keep French fries hot. It also causes the heat you feel from ordinary light bulbs. Since carbon dioxide absorbs this heat, the more carbon dioxide there is in atmosphere, the warmer the air will be. If the air gets too hot, the balance of life will be disrupted. Species of plants and animals will die. The food chain could be upset. This would cause many serious problems worldwide.

Between 1961 and 2000, average world crop yields grew rapidly, much more quickly than they had in the preceding millennia that humans have been growing domesticated crops. The rapid growth was a result of the Green Revolution, a concerted international effort to exploit advances that had been made in crop breeding, fertilizers and herbicides. The Green Revolution strategy emerged from a surprising confluence of different lines of agricultural research (Evans, 1998) - the development of cheap nitrogenous fertilizers, of dwarf varieties of major cereals, and of effective weed control. Nitrogenous fertilizers increase crop production substantially, but make plants top-heavy, causing them to fall over.

The development of dwarf varieties solves this problem, but at the cost of making plants highly susceptible to weeds, which grow higher than the dwarf plants, depriving them of light. The development of effective herbicides removed this problem. Further Green Revolution development focused on crop breeding to increase the harvest index - the ratio of the mass of grain to total above-ground biomass.

\section{Temperature stress on reproductive growth}

Plant Reproduction is highly vulnerable to environmental conditions such as temperature and consequently, planet warming may have significant consequences on the reproductive phase with serious implication in agricultural crops. Although pollen tube growth is clearly affected by temperature, little information is available on its effect on the female side and on flower receptivity (Hedhly et al. 2003).

Decreased fruit- set at higher temperature was mainly due to poor pollen viability, reduce pollen production and poor pollen tube growth, all of which lead to poor fertilization of flowers (Prasad et al., 2003). Flower abortion also has been attributable to the decreased seeds per plant and seed yield in other crops such as Brassica napus (Angadi et al., 2000) B rapa (Morrison and Stewart, 2002) and B. Juncea (Gan et al., 2004).

Pollen development, fertilization, and asynchrony of stamen and gynoecium's development are sensitive to temperatures during flowering (Prasad et al., 1999; Croser et al., 2003; Boote et al., 2005). The lost of pollen or stigma viability under high temperatures stress might be the primary reason for the lowered number of seeds produce in the legume (Srinivasan et al., 1998; Davies et al., 1999; Hall, 2004).

Significant negative correlation between pollen production and temperature were found in groundnut (Prasad et al., 1999).Lower seed yield at high temperature under both ambient and elevated $\left[\mathrm{CO}_{2}\right]$ conditions was shown to be due to decreased pollen viability in groundnut and bean (Prasad et al., 2002, 2003). Pollen sterility and pollen production at high temperatures may also be associated with early degeneration of the tapetal layer of pollen (Porch and Jahn, 2001).The exact physiological reasons of pollen viability loss are not clearly known and need further investigation (Sailaja et al., 2005).

Reproductive growth leading to seed yield is often depressed by the same increase in temperature that enhances vegetative growth and development. Flower initiation was reduced by temperature $>32^{\circ} \mathrm{C}$ and seed formation was delayed at $40-30^{\circ} \mathrm{C}$ (Thomas et al., 2003). When soybean plants were exposed to temperature of $35^{\circ} \mathrm{C}$ for $10 \mathrm{~h}$ during the day, yield reductions of about $27 \%$ were measured (Gibson and Mullen, 1996). Hence, it is essential to protect crop yield from higher and more frequent episodes of extremely higher temperature both in current and future climates (Salem et al., 2007).

Gan et al. (2004) found that the seed yield of canola decrease by 15\% when high temperature stress was applied before flowering, whereas the yield reduction was 58\% when the stress was delayed to the period of flowering, and further to $77 \%$ when the stress was delayed to the pod developmental stage. Physiologically, the high temperature stress during reproductive development may have affected flower abortion, sequent sink site, and later pod abscission resulting a decreased number of seeds per plant (Duthion and Pigeaire, 1991). Also, high temperature stress during reproductive development may have negatively affected cell expansion, cotyledon cell number and thus seed filling rate, resulting in the lowered weight per seed (Munier- Jolain and Ney1998). 
Successful fruit set depends on several reproductive processes including pollen germination and tube growth processes. Sexual reproduction in plants is more sensitive to high temperatures than vegetative process, and therefore plant reproductive organs will be more vulnerable to changes in short episodes of high temperatures prior to and during early flower stage (Reddy and Kakani, 2007).

\section{Global warming effect on soybean production}

Soybean (Glycine max L.) Merrill, has become the major source of edible vegetable oils and high protein feed supplements for livestock in the world. About $90 \%$ of the world's soybean production occurs in the tropical and semi-arid tropical region, which are characterized by high temperature and low or erratic rainfall. In the tropic, most of the crops are near their maximum temperature tolerance; therefore crop yield may decrease even with minimal increases in temperature.

Temperature has a great influence on the distribution, growth, yield and quality in soybean. It is sensitive to temperature change. The suitable temperature for soybean is $15-22{ }^{\circ} \mathrm{C}$ at emergence, $20-25{ }^{\circ} \mathrm{C}$ at flowering, and $15-22{ }^{\circ} \mathrm{C}$ at maturity (Liu et al., 2008). Soybean seed yield components are also influenced by temperature. Soybean seed yield increased as temperature increased between $18 / 12$ (day/night) and $26 / 20^{\circ} \mathrm{C}$, but yield decrease (when plants were grown at temperature) greater than $26 / 20^{\circ} \mathrm{C}$ (Huxley et al., 1976; Sionit et al., 1987). Raising temperature from $29 / 20$ to $34 / 20^{\circ} \mathrm{C}$ during seed fill decreased soybean seed yield (Dornobos and Mullen, 1991).

Reproduction plays an important role in the survival and succession of seed crop plants. The onset of the reproductive phase, its duration, and the quality and quantity of reproductive products are regulated by abiotics factors. Of the various abiotic factors, atmospheric temperature and $\mathrm{CO}_{2}$ concentration are subject to change in the near future. The climate change factors being tested in this study modify reproductive organs and processes. Elevated $\left[\mathrm{CO}_{2}\right]$ and high temperature increased flower production in soybean (Nakamoto et al., 2001; Zheng et al., 2002).

Successful cultivation of soybean in the tropic requires the availability of high quality planting seed. Local production of such seed requires cultivars capable of enduring adverse climatic conditions usually present during the later stages desirable in the subtropics because high soil temperature at planting and crusting of the soil surface may result in poor stands (Koti et al., 2004).

\section{Temperature stress on seed yield and pollen quality}

Seed yield of determinate soybean is produced on both the main stem and branches originating from main stem nodes (Board, 1987). Branch initiation usually occurs first at the cotyledon node prior to vegetative growth stage (Fehr et al., 1977), followed by branch initiation at the unifoliolate node between growth stages (Acock and Acock, 1987). However, most branch vegetative growth does not occur until between reproductive growth stages (Fehr et al., 1977). A majority of the seed yield of determinate soybean is produced on these branches originating from the main stem (Board, 1987). Stresses that reduce crop growth rate between growth stages result in the greatest seed-yield decreases (Linkemer et al., 1998). These results indicate that branch seed yield of determinate soybean is dependent on the amount of branch vegetative growth that occurs during the flowering and pod formation stages of development. Less is known about the effects of temperature stress on soybean branch growth and branch seed yield or how temperature stress affects the distribution of seed yield between the main stem and branches (Frederick et al., 2001).

The number of pods per plant generally increased as temperatures increased to near $26 / 20^{\circ} \mathrm{C}$. Plants grown at temperature exceeding $26 / 20^{\circ} \mathrm{C}$ had decreased pod numbers (Huxley et al., 1976; Thomas and Raper, 1978; Sionit et al., 1987). During flowering and pod set, temperatures as high as $30 / 20^{\circ} \mathrm{C}$ favored greater pod set (Lawn and Hume, 1985), but temperatures above $40^{\circ} \mathrm{C}$ severely limited pod formation (Mann and Jaworski, 1970). Seeds per plant increased as temperatures from early vegetative growth to maturity increased from $18 / 12$ to $26 / 20^{\circ} \mathrm{C}$ and $26 / 19$ to $36 / 29^{\circ} \mathrm{C}$ (Baker et al., 1989). Season- long night temperature increases from 10 to $24 \mathrm{C}$ did not influence seed number (Seddigh and Jolliff, 1984). In contrast to these findings, Huxley et al. (1976) observed fewer seeds per plant when day temperature was raised from 27 to $33^{\circ} \mathrm{C}$ and night temperature was increased from 19 to $24^{\circ} \mathrm{C}$. Increase in temperature from $29 / 20$ to $34 / 20^{\circ} \mathrm{C}$ during seed fill resulted in fewer seeds per plant (Dornbos and Mullen, 1991). Seeds per pod was the seed yield component least affected by temperature (Huxley et al., 1976; Sionit et al., 1987; Baker et al., 1989).

Weight per seed in soybean was increases in season-long temperatures from $18 / 12$ to $26 / 20^{\circ} \mathrm{C}$ (Sionit et al., 1987), but as temperature increased above $26 / 20^{\circ} \mathrm{C}$, weight per seed decreased (Hesketh et al., 1973; Huxley et al., 1976; Baker et al., 1989). Temperatures above $30 / 25^{\circ} \mathrm{C}$ during flowering and pod development reduced weight per seed, regardless of the temperature during seed fill (Egli and Wardlaw, 1980). Temperatures above $29 / 20^{\circ} \mathrm{C}$ during seed fill decreased soybean weight per seed (Dornbos and Mullen, 1991). Unfavorable growing conditions, such as late planting, excessive soil water, and high plant populations, reduce soybean seed yield primarily by reducing branch growth and branch seed yield per plant (Frederick et al., 1998; Linkemer et al., 1998). Stress that reduce crop growth rate between growth stage R1 and R5 result in the greatest seed- yield decreases (Board and Harville, 1998). 
A major obstacle to the expansion of soybean [Glycine max (L.) Merrill] production to new areas of the tropic is the difficulty in producing high quality seed. Tropical conditions of high relative humidity and temperature during soybean seed production both before and after the reaches a harvestable moisture level are not conducive to production of high quality seed necessary to establish acceptable stands (Tekrony et al., 1980). Seed vigor is an important parameter which needs to be assessed to supplement germination and viability tests to gain insight into the performance of a seed lot in the field. Seed quality has great impact on the quality of planting stock. The uniformity of seed development within the crop is a major factor through which crop production practices and growing condition will affect seed-to-seed variation. During the growth of field crops, maximum seed quality is generally regarded to be attained at physiological maturity (PM), i.e., at the end of seed filling (Egli, 1998).

The crop is harvest at harvest maturity (HM), when seeds have dried to a moisture content that allows harvesting without considerable damage. By the time seed quality may already have deteriorated. Because seed development within a crop is not uniform, there are differences in the moment individual seeds reach PM. In soybean, longer exposure of early pods to deteriorating conditions was thought to explain the lower viability at harvest of seeds from earlier compared with late pods (Illipronti Jr et al., 2000). Poor seed quality can be cause by the effect of pathogens before physiological maturity, pre-harvest weathering, mechanical damage during and after harvest and deterioration during storage. Hot, dry weather during seed maturation can also result in poor quality (FAO, 1994). It is unlikely that temperature has much effect on seed quality, although that possibility has not been explored. Seed quality is however, sensitive to temperature during the seed-filling period. Because high temperature can differentially affect the various processes involved in seed filling, warming can affect seed composition. In addition seeds are smaller at high temperature, their milling quality can suffer.

In seed plants, successful fertilization requires correct regulation of pollen tube growth. At germination and during growth, the pollen tube interacts with tissue from the pistil while the pollen tube extends via tip growth. Despite the fact that much research has been devoted to the mechanisms regulating pollen tube growth, many aspects are currently unknown.

Plant growth and development, particularly reproductive processes such as pollen grain, pollen tube growth, and fruit set are effected by the temperature more than by any other environmental factor when water is not a limiting factor. Environmental stresses prevailing during pollen development, germination and pollen tube growth affect the functioning of the pollen and eventual fruit and seed set.

Temperature has a clear effect on pollen tube kinetics, expressed as the time required for pollen germination and the rate of pollen tube growth. While temperature affects pollen tube kinetics, information on the effect of temperature on pollen tube dynamics, expressed as the census of the microgametophyte population that succeeded to reach the base of the style, is missing (Hedhly, et al., 2004).

Pollen grains once released from anthers act as independent functional units and are exposed to ambient environment. Therefore, episodes of high temperature during flowering would more severely affect pollen than the deeply seated ovules. Recent studies have shown that micro-and mega-sporogenesis are injured by high temperature, resulting in reduced fruit set (Cross et al., 2003; Young et al., 2004) but they also suggest that pollen plays a major role in fruit-set under high temperature conditions.

Yield decrease due to high temperature and $\left[\mathrm{CO}_{2}\right]$ could be due to the effect of on reproduction at both organ and process levels. High temperature inhibits pollen germination and pollen tube growth and genotypes differ in their sensitivity (Huan et al., 2000; Kakani et al., 2002). Plants to exhibit greater reproductive survivability at extreme (low and high) temperatures normally encountered during plant reproduction and for processes leading to yield such as pollen grain development, pollen germination, pollen tube growth, fertilization and embryo development, and finally seed development.

\section{Conclusion}

Future population growth will place additional demands on crop production. There is scope for both increase yield and expanded cropland area, though that scope varies among regions. In addition to increasing food demand, both population and standard of living increase are bringing with them environmental changes at local, regional, and global spatial scales, and across temporal scales ranging from years to centuries. Many of those environmental changes have important implications, some positive and others negative, for future crop yield and production. Crop breeding and management have the potential to mitigate the negative and reinforce the positive effects of environmental changes on crop physiology and yield. Adaptation by farmers and researchers may be the most important response to these changes. The success of such adaptation might be fostered by basic understanding of effects of environmental changes on crop physiology and growth. This is, at least, one view. I n some case, the degree to which adaptation will be successful, or even possible, may depend on the rate of environmental changes (e.g., the rate of warming during coming decades). Unfortunately, certain knowledge of those rates will be obtained only with the passage of time, and by then it may be too late for effective action. 
A better understanding of the influence of high temperature during reproductive growth on soybean seed yield and quality is needed. Although pollen may successfully fertilize an ovule, enhanced high temperature may stay reduce seed production by inducing abortion? The clear effect of high temperature on pollen production and pollen grain germination will have major implications on the fertilization process and fruit set in sensitive crop under future climates. Further studies to relate pollen germination to fruit set are needed. The practices of high-input agriculture are causing concerns about the sustainability of crop production. There are many negative effects on the environment, including pollution by pesticides, emission of greenhouse gases, soil degradation, air pollution by dust, and loss of landraces and other biodiversity. People need to develop new techniques that will keep agriculture both profitable for the farmer and make it sustainable for the future.

This paucity of information along with these variable responses makes it difficult to predict the consequences of enhanced high temperature on pollen production and plant reproductive success. In reality, plants in nature are exposed to multiple environmental conditions concomitantly, and their performance can be assessed only when plants are grown in multiple stress conditions. The impact of global warming will impose great physiological constraints to crop productivity in the tropic. To be successful the researchers will need funding support from government and they will also need to forge linkages with other scientists dealing with this problem in the world. New biotechnological techniques will also need to be applied to face the challenge of global warming. Giving the nature of agricultural production in much of the world today and the challenges facing agriculturally-based economics, we can not be sanguine about the prospects for agricultural productivity, the availability of cropland, or for the environment. Through policy, politic, and global cooperation, we may reduce the environmental problems that cause global warming.

\section{Acknowledgement}

The authors are grateful to the Oil Crops Development Project (UTF/MYA/006/Mya) in Myanmar initiated by the Ministry of Agriculture and Irrigation, Myanmar and technical assistance by FAO for granting a fellowship for the first author.

\section{References}

Acock B and MC Acock. (1987). Periodic shading and location and timing of branches of soybean. Agron.J., 79:949-952.

Ahmed FE, Hall AE, Madore MA. (1993). Interactive effects of high - temperature and elevated carbon dioxide concentration on Cowpea (Vigna unguiculata L. Walp). Plant Cell and Environment, 16, 835-842.

Angadi SV, HW Cutforth, PR Miller, BG Mc Conkey, MH ENTZ, K-Volkmar, and S Brandt. (2000). Response of three Brassica species to high temperature injury during reproductive growth. Can. J Plant Sci., 80:693-710.

Baker J.T, Allen L H Jr, Boote KJ et al. (1989). Response of soybean to Air temperature and carbon dioxide concentration. Crop Sci, 29, 98-105.

Beggs, P.J. (2004). Impacts of climate change on aeroallergens: past and future. Clin Exp Allergy, 34: 1507-1513.

Board, J.E. 1987.Yield Components related to seed yield in determinate soybean. Crop Sci., 27:1296-1297.

Board, J.E., and B.G. Harville. (1998). Late-planted soybean yield response to reproductive source/sink stress. Crop Sci., 38:763-771.

Boote, K.J., L.H.Aleen, P.V.V.Prasad, J.T.Baker, R.W.Gesch, A.M.Snyder, D-Pan, and J.M.G.Thomas. (2005). Elevated temperature and carbon dioxide impacts on pollination, reproductive growth, and yield of several globally important Crops. J. Agric. Metero.Japan 60:469-474.

Croser, J.S., H.J.Clarke, K.H.M.Siddque, and T.N.Khan. (2003). Low temperature stress: implications for chickpea (Cicer arietinum L.) improvement. Crit. Rev. Plant Sci, 22:185-219.

Cross RH, Mc Kay SAB, Mc Hughen AG, Bonham-Smith PC. (2003). Heat stress effects on reproduction and seed set in Linum usitatissimum L. (flax). Plant, Cell and Environment, 26: 1013-1020.

Davies, S.L, N.C.Turner, K.H.M.Siddique, J.A Plummer, and L. Leport. (1999). Seed growth of desi and kabuli chickpea (Cicer arietinum L) in a short-season Mediterranean-type of environment. Aus. J. Exp. Agric., 39:181-188.

Dornbos, D.L., Jr., and R.E.Mullen. (1991). Influence of stress during soybean seed fill on seed weight, germination, and seedling growth rate. Journal of Plant Science, 71: 373-383.

Duthion, C., and A.Pigeaire. (1991). Seed Lengths corresponding to the final stage in seed abortion of three grain Legumes. Crop Sci., 31:1579-1583.

Egli, D.B. (1998). Seed biology and the yield of grain crops. CAB International, Wallingford, 178pp.

Egli, D.B., and I.F.Wardlaw. (1980). Temperature response of seed growth characteristics of soybeans. Agronomy Journal, 72: 560-564. 
Egli, D.B, D.M.Tekrony, J.J. Heitholt, and J. Rupe. (2005). Air temperature during Seed filling and soybean seed germination and vigor. Crop Sci., 45:1329-1335.

Evans, L.T. (1998). Feeding the Ten Billion: Plants and Population Growth. Cambridge: Cambridge University Press.

FAO. (1994). Food and Agriculture Organization of the United Nations. Tropical Soybean: Improvement and production. FAO Plant Production and Plant Protection paper, FAO, Rome. 27:1pp.

Fehr, W.R. and C.E Caviness. (1977). Stages of soybean development. SREC. Rep.80.Lowa Agric. Home Econ. Exp. Stn., Lowa State University, Ames, IA.

Frederick, J.R., P.J.Bauer, W.J.Busscher, and G.S.Mc Cutcheon. (1998). Tillage management for double cropped soybean grown in narrow and wide row width culture. Crop Sci., 38:755-762.

Frederick, J.R., Camp, C.R, and Bauer P.J. (2001). Drought- stress effects on branch and main stem seed yield and yield components of determinate soybean. Crop Sci., 41:759-763.

Gan, Y., S.V.Angadi, H.W.Cutforth, D.Potts, V.V.Angadi, and C.L.Mc Donald. (2004). Canola and mustard response to short period of high temperature and water stress at different developmental stages. Can. J. Plant Sci., 84:697-704.

Gibson, L.R., and R.E. Mullen. (1996). Soybean seed quality reductions by high day and night temperature. Crop Sci., 36: 1615-1619.

Hall, A.E. (1992). Breeding for heat tolerance. Plant Breeding Review, 10, 129-168.

Hall, A.E. (2004). Breeding for adaptation to drought and Heat in Cowpea. Eur. J. Agronomy, 21:447-454.

Hedhly A. Hormaza JI. And Herrero M. (2003). The Effect of temperature on stigmatic receptivity in Sweet Cherry (Prunus avium L.) Plant Cell and Environment, 26, 1673-1680.

Hedhly, A., J.I.Hormaza and M.Herrero. (2004). Effect of temperature on pollen tube kinetics and dynamics in sweet cherry, Prunus avium (Rosaceae). American Journal of Botany, 91 (4): 558-564.

Hesketh, J.D., D.L.Myhre, and C.R.Willey. (1973). Temperature control of time intervals between vegetative and reproductive events in soybeans. Crop Sci., 13: 250-254.

Houghton, J.T., Ding Y, Griggs D.J et al. (2001). Climate change 2001: The Scientific Basis (Contribution of Working Group to the Third Assessment Report to the Intergovernmental Panel on Climate Change (IPCC). Cambridge University Press, UK.

Huan F, Lizhe A, Ling Ling T, Zong Dong H, X unling W. (2000). Effect of enhanced Ultraviolet-B radiation on pollen germination ad tube growth of 19 Taxa in vitro. Environment and Experimental Botany, 43, 45-53.

Huxley, P.A., R.J.Summerfied, and P.Hughes. (1976). Growth and development of soybean CV-TK5 as affected by tropical day lengths, day / night temperatures and nitrogen nutrition. Ann. Apply. Biol., 82:117-133.

Illipronti Jr, R.A., W. J. M. Lommen, C.J.Langerk \& P.C. Struik. (2000). Time of pod set and seed position on the plant contribute to variation in quality of seeds within soybean seed lots. Netherlands Journal of Agricultural Science, 48: 165-180.

Kakani VG, Prasad PVV, Craufurd PQ, Wheeler TR. (2002). Response of in vitro pollen germination and pollen tube growth of Groundnut (Arachis hypogaea L.) genotype to Temperature. Plant Cell and Environment, 25, 1651-1661.

Kaufmann RK, Stren DI. 1997. Evidence of human influence on climate from hemispheric temperature relations. Nature, 388, 39-44.

Koti, S, K. R.Reddy, V.G. Kakani, D. Zhao and V.R. Reddy. (2004). Soybean (Glycine max L.) Pollen germination characteristics flower and pollen morphology in response to enhanced ultraviolet-B radiation. Annals of Botany, 94: 855-864.

Lawn, R.J., and D.J. Hume. (1985). Response of tropical and temperature soybean genotypes to temperature during early reproductive growth. Crop Sci., 25:137-142.

Linkemer, G., J.E.Board, and M.E.Musgrave. 1998. Water logging effects on growth and yield components in lateplanted soybean. Crop Sci., 38:1576-1584.

Liu, X. J. Jian, W. Guanghua, and S.J. Herbert. (2008). Soybean yield physiology and development of high- yielding practices in Northeast China. Field Crops Research, 105: 157-171.

Mann, J. D., and E.G. Jaworski. (1970). Comparison of stresses which may limit soybean yields. Crop Sci., 10: 620-624.

Morrison, M.J., and D.W.Stewart. (2002). Heat Stress during Flowering in Summer Rape. Crop Sci., 42:797-803. 
Munier-Jolain, N.G., and B.Ney. (1998). Seed Growth Rate in Grain Legumes II. Seed Growth rate depends on cotyledon cell number. J.Exp.Bot., 49:1971-1976.

Nakamoto H, Zheng S, Furuya T, Tanaka K,Yamazaki A, Fukuyama M. (2001). Effects of long- term exposure to atmospheric carbon dioxide Enrichment on Flowering and poding in soybean. Journal of the Faculty of Agriculture (Kyushu University) 46, 23-29.

Petil JR, Jouzel J, Raynaud D et al. (1999). Climate and atmospheric history of the Past 420,000 years from the Vostic Ice Core, Antarctica. Nature, 399,429-436.

Porch TG, Jahn M. (2001). Effect of high temperature stress on microsporogenesis in heat- sensitive and heat- tolerant of Phaseolus vulgaris. Plant Cell and Environment, 24, 723-731.

Prasad PVV, Craufurd PQ, Summerfield RJ. (1999). Fruit number in relation to pollen production and viability in groundnut exposed to short episodes of heat stress. Annals of Botany, 84, 381-386.

Prasad PVV, Craufurd PQ, Summerfield RJ. (2000). Effect of high air and soil temperature on dry matter production, pod yield and yield components of Groundnut. Plant and Soil, 222,231-239.

Prasad PVV, Boote KJ, Allen LH Jr et al. (2002). Effects of elevated temperature and carbon dioxide on seed-set and yield of Kidney Bean (Phaseolus vulgaris L.). Global Change Biology, 8, 710-721.

Prasad PVV, Boote KJ, Allen LH, Thomas JMG. (2003). Super optimal temperatures are detrimental to Peanut (Arachis hypogaea L.) reproductive processes and yield at both ambient and elevated carbon dioxide. Global Change Biology, 9, 1775-1787.

Reddy, K.R. (2005). Crops and environmental change: An introduction to effect of global warming. Crop Sci. 45:6; ProQuest Agriculture Journals. P-2674.

Reddy K.R. and V.G. Kakani. (2007). Screening Capsicum species of different origins for high temperature tolerance by in vitro pollen germination and pollen tube length. Science Direct. Scientia Horticulturae, 112, 130-135.

Reynolds, M. P., S. Nagarajan, M. A., razzaque and O. A. A. Ageeb. (2001). Heat Tolerance. Application of Physiology in Wheat Breeding. CIMMYT. P124-135.

Sailaja K.et al. (2005). Interactive effects of carbon dioxide, temperature, and UV-B radiation on Soybean (Glycine max L.) Flower and pollen morphology, pollen production, germination, and tube length. Journal of Experimental Botany, 56,725-736.

Salem, M.A, V.G.Kakani, S.Koti, and K.R.Reddy. (2007). Pollen-based screening of soybean genotype for high temperatures. Crop Sci., 47:219-231.

Seddigh, M. and G.D. Jolliff. (1984). Effect of night temperature on dry meter partitioning seed growth of intermediate field grown on soybean. Crop Science Society of America, 24:44, 704-710.

Sionit, N., Strain, B. R. \& Flint, E. P. (1987). Interaction of temperature and $\mathrm{CO}_{2}$ enrichment on soybean: Growth and dry matter partitioning. Can. J. Plant Sci., 67: 59-67.

Srinivasan, A., C. Johansen, and N.P.Saxena. (1998). Cold tolerance during early reproductive growth of Chickpea (Cicer arietinum L); Characterization of stress and genetic variation in pod set. Field Crop Res., 57:181-193.

Stainforth, D. A., T. Aina, C. Christensen, M. Collins, N. Faull, D. J. Frame, J. A. Kettleborough, S. Knight, A. Martin, J. M. Murphy, C. Piani, D. Sexton, L. A. Smith, R. A. Spicer, A. J. Thorpe, and M. R. Allen. (2005). Uncertainty in predictions of the climate response to rising levels of greenhouse gases. Nature, 433, 403-406.

Stott PA, Tett SFB, Jones GS et al. (2001). Attribution of twentieth century temperature change to natural and anthropogenic causes. Climate Dynamics, 17, 1-21.

Tekrony, D.M., D.B.Egli and A.D.Phillips. 1980. Effect of weathering on viability and vigor of soybean seed. Agron. J. 72:749-753.

Thomas, J.F., and C.D. Raper, J.R. (1978). Effect of day and night temperatures during floral induction on morphology of soybeans. Agrono. J., 70: 893-898.

Thomas, J.M.G., K.J.Boote, L.H.Allen, Jr., M.Gallo- Meagher, and J.M.Davis. (2003). Elevated temperature and carbon dioxide effects on soybean seed germination and transcript abundance. Crop Sci., 43: 1548-1557.

Young LW, Wilen RW, Bonham-Smith PC. (2004). High temperature stress of Brassica napus during flowering reduces micro- and mega gametophyte fertility, induces fruit abortion, and disrupts seed production. Journal of Experimental Botany, 55:485-495

Zheng S, Nakamoto H, Yoshikawa K, Furuya T, Fukuyama M. (2002). Influences of high night temperature on flowering and pod setting in soybean. Plant Production Science, 5, 215-218. 